\title{
Tax Sustainability: The Effectiveness and Contribution of Land and Building Taxes to Regional Original Revenue in Yogyakarta City, Indonesia
}

\author{
Wulan Dari ${ }^{1}$, Samsul Bakri ${ }^{2}$, Nany Noor Kurniyati ${ }^{3}$, Anamonce Sondega ${ }^{4}$ \\ 1,2,3,4 Widya Mataram University, Yogyakarta \\ ${ }^{1}$ Goethe University, Frankfurt am Main
}

\begin{abstract}
The principle of decentralization has been emphasized since the existence of regional autonomy to manage its resources. Various regional regulations that originally had to be approved by the central government in advance, can be set by regional heads independently. With regional autonomy, it is hoped that the investment procedure will be easier so that the potential of the region can be utilized as much as possible to increase Regional Original Revenue (PAD) in the region. Tax revenue is one of the sustainable aspects in order to increase Regional Original Revenue. Land and Building Tax in Indonesia (PBB) has the potential to support regional revenue in order to implement regional autonomy and development. The aims of this study are: (1) to determine the growth of Yogyakarta's land and building tax revenue in 2016-2020, (2) to determine the effectiveness of Yogyakarta's land and building tax revenue based on 2016-2020 clarification, (3) to determine the contribution land and building tax on local revenue of Yogyakarta in 2016-2020. The population in this study is the government of the Yogyakarta City. This study uses a quantitative descriptive method. Data collection techniques through documentation, interviews and observation. The data used in this research is (radom sampling). That is, in this study, it is secondary data, namely data collected from the Regional Assets and Management Agency in the form of reports on the Realization of Land and Building Taxes and Regional Original Revenue (PAD) of Yogyakarta during the 2016-2020 period. Potential land and building taxes and the realization of local revenue. Data were analyzed using effectiveness analysis, and contribution analysis. The results of the study can be concluded (1) The highest land and building tax growth was obtained in 2020 of 116.99\% and the lowest growth was obtained in 2018 of $101.87 \%$. (2) Land and building tax revenue in Yogyakarta Municipality based on the clarification of 20216-2020 is very effective. (3) Yogyakarta Municipality's land and building tax revenue contributes less to the Regional Original Income.
\end{abstract}

KEYWORDS: tax sustainability, land and building tax, tax contribution, regional original revenue

\section{INTRODUCTION}

Local taxes can be done with a centralized or decentralized approach. The centralized approach is to concentrate all authority on a small number of managers or those in top positions in an organizational structure (Nuradhawati, 2019). While the decentralization approach is the granting of authority to all areas of government that are fully responsible to the city and district areas. The principle of decentralization has been emphasized since the existence of regional autonomy to manage its resources. Various regional regulations that originally had to be approved by the central government in advance, can be set by regional heads independently. With regional autonomy, it is hoped that the investment procedure will be easier so that the potential of the region can be utilized as much as possible to increase Regional Original Revenue in the region.

Regional autonomy is implemented in stages, the central government has transferred various authorities in an effort so that the government can manage the region so that it is more developed. The implementation of regional autonomy and fiscal decentralization over the last ten years still needs continuous improvement. One such effort is fiscal decentralization with management and revenue, in this case taxes and retribution. Tax revenue is one of the important aspects in order to increase Regional Original Revenue.

Regional Original Revenue itself is regional revenue that comes from pure regional revenue sources and is used to finance regional development. For this reason, Regional Original Revenue must be pursued as best as possible so that it always increases in line with improving services to the community. In the history of local government in Indonesia, since Indonesia's independence 


\section{Tax Sustainability: The Effectiveness and Contribution of Land and Building Taxes to Regional Original Revenue in Yogyakarta City, Indonesia}

until now, local taxes and retributions have become a reliable source of revenue for the regions. However, in general for regencies/cities, the contribution from taxes is quite good, regional rentributions on the State Revenue Expenditure Budget in Indonesia (APBN) are very varied according to the potential of each region. Together, Regional Original Revenue in Indonesia (PAD) has a significant influence on regional expenditures. So that it can be said that local governments in carrying out annual expenditures are influenced by the amount of Regional Original Revenue.

The amount of Regional Original Revenue is obtained from various taxes that exist in an area. In this case, the Yogyakarta city government manages 11 types of taxes, namely: Hotel Tax, Restaurant Tax, Entertainment Tax, Street Lighting Tax, Parking Tax, Land Tax on Water,

Bird's nest wallet tax, Land and building tax, Advertising Tax, Tax on Intake of Non-Metal and

Stone Minerals. One of the types of taxes listed above will be discussed in this study, namely the Land and Building Tax. Land and Building Tax in Indonesia (PBB) has the potential to support regional revenue in order to implement regional autonomy and development (McCluskey, William J. \& Plimmer, 2011). Land and Building Tax should be able to provide substantial revenue in the tax sector (Norregaard, 2013).

Officially in Indonesia, on January 1, 2010 the era of regional autonomy was enacted, in which the central government wanted every region in Indonesia to be able to find its own source of income to finance regional needs or expenditures in administering government and development, which means in that era, regions were really required to be more independent in implementing government and development and not relying on the central government. The distribution of finance between the central government and regional governments in which the implementation of their duties and authorities at each level of government requires funding support. It means that local governments are required to have financial independence because assistance from the central government which is the source of the Regional Revenue Expenditure Budget in Indonesia (APBD) begins to reduce its contribution, so that what is now the source of the APBD is Regional Original Revenue. One of the Regional Original Revenue (PAD) comes from local taxes, one of which has increased from year to year is the land and building tax. By looking at the contribution of land and building taxes in recent years, it can be said that the land and building tax in Yogyakarta is one source of Regional Original Revenue (PAD) which has the potential to always be increased. Based on this, it is necessary to know how much effectiveness the collection of land and building taxes is and how much it contributes to local revenue.

Effectiveness is a measure of the success or failure of an organization in achieving its goals (Halim, 2012). Effectiveness is a multilevel achievement of the results of work programs with predetermined targets (Kadir, 2017). Effectiveness is a condition that occurs as a desired result. If it is related to land and building tax revenues, effectiveness is how much land and building tax revenue is realized that must be achieved in a certain period (Fitriani, Handayan, \& Z.A, 2015). So that it can be known whether the collection of land and building taxes has been effective or not. While the local contribution is a premium or donation. Local contributions can be used as a benchmark for the level of contributions that have been given to Regional Original Revenue (PAD) receipts. If it is associated with land and building tax contributions, then the local contribution is how much the preimum rate or donation from land and building taxes to the amount of local revenue.

The difference between this study and the previous one is in the research location, the period used for research and the amount of land and building tax revenue received by the region due to the area. Judging from previous research, research related to the effectiveness and contribution of land and building taxes to the increase in Regional Original Revenue results in the effectiveness of land and building tax revenues on increasing Regional Original Revenue, which is included in the very effective criteria. Do the land and building tax revenue has very big contribution in increasing Regional Original Revenue in Yogyakarta? The level of effectiveness and contribution from land and building tax revenues to local revenue can be used as input for the Yogyakarta government in determining policies regarding tax revenues, especially land and building taxes.

\section{LITERATURE REVIEW \\ Land and Building Tax}

Land and Building Tax (Pajak Bumi dan Bangunan / PBB) is a state tax imposed on land and buildings based on Law No. 12 of 1994. PBB is a tax that is material in nature in the sense that the amount of tax payable is determined by the condition of the object, namely the land/land and/or building. Land and Building Tax (PBB) is a type of tax that is fully regulated by the government in determining the amount of tax (adhering to the official assessment system collection system). Here the state of the subject (who pays) does not determine the amount of tax. (United Nations Billing Section. Regional Revenue, Financial and Asset Management Office. 2012. No. 12 of 1994 Land and Building Tax. Gresik: Regional Revenue, Financial and Asset Management Office). 


\section{Tax Sustainability: The Effectiveness and Contribution of Land and Building Taxes to Regional Original Revenue in Yogyakarta City, Indonesia}

\section{Regional Original Revenue (Pendapatan Asli Daerah / PAD)}

Based on Law No. 33 of 2004 concerning Financial Balance between the Center and the Regions Article 1 point 18 that local revenue is income earned by the region based on regional regulations in accordance with statutory regulations.

According to Natalia Rawun (2016), Regional Original Revenue is income obtained by the region which is collected based on regional regulations in accordance with applicable laws and regulations, and aims to give authority to regional governments to fund the implementation of regional autonomy in accordance with regional potential, so that the analysis of Regional Original Revenue become one of the important factors in achieving financial resources. Regional Original Revenue is revenue that comes from within the area concerned in order to finance the activities of the area. Regional original income as a source of regional revenue itself needs to be continuously increased so that it bears the burden of spending needed for government administration and development activities every year so that the independence of regional autonomy is broad, real, and responsible.

According to Luthfi (2015), "Regional Original Revenue (PAD) is the regional government obtaining income from sources that are collected by themselves in accordance with applicable laws". Sources of Regional Original Revenue (PAD) are as follows:

a. Local tax

b. Regional retribution;

c. Revenue of regional owned enterprises and management of other separate regional assets;

d. Other legit "regional original income" as follows:

1. "regional fixed asset sales"

2. "giro services"

\section{Contribution of the Land and Building to Regional Original Revenues (PAD)}

According to Mahmudi (2010), contributions are used to determine the extent to which local taxes can contribute or contribute to local revenue receipts. To find out the contribution, it can be done by comparing local tax revenues with Regional Original Revenues. Land and Building Tax Contributions are collections made by the government to the entire community to increase tax revenues, which are generated through process implementation activities based on systems and procedures in tax collection. which has been applied in order to increase Regional Original Revenues.

The author can conclude that the contribution is a way to measure or find out how big the contribution given by local taxes, especially the Land and Building Taxes to the realization of Regional Original Revenue.

Local taxes get a large contribution if the results of the calculation have a percentage of more than $50 \%$. To find out how big the contribution of the Land and Building Taxes can be used the following indicators.

Table 1. Interpretation of Contribution Value

\begin{tabular}{|l|l|}
\hline Presentasi & Kriteria \\
\hline $0,00-10 \%$ & Sangat Kurang \\
\hline $10,10-20 \%$ & Kurang \\
\hline $20,10-30 \%$ & Sedang \\
\hline $30,10-40 \%$ & Cukup Baik \\
\hline $40,10-50 \%$ & Baik \\
\hline Diatas $50 \%$ & Sangat Baik \\
\hline
\end{tabular}

Source: Research and Development Team of the Ministry of Home Affairs-Fisipol UGM

\section{Effectiveness of Land and Building Tax}

Effectiveness in general is a measure used to measure the extent to which a set goal or target has been achieved. Effectiveness is a measure of the success or failure of an organization to achieve its goals (Ulum, 2012). If an organization succeeds in achieving its goals, then the organization is said to have been running. Effectiveness focuses on achieving results. Effectiveness is the utilization of resources, facilities and infrastructure in a certain amount that is consciously determined beforehand to produce a number of jobs on time (Abdurrahmat, 2003). Effectiveness is a measure of the success or failure of an organization in achieving its goals (Mardiasmo, 2011). If the determined regional goals are successfully achieved by the regional government, then the region is said to have been effective in managing PBB revenues.

Effectiveness is a measure used to measure the relationship between the results of a tax levy received with the tax revenue target set. Based on the definition of effectiveness, which is meant for PAD in terms of the effectiveness of PBB revenue, is the 


\section{Tax Sustainability: The Effectiveness and Contribution of Land and Building Taxes to Regional Original Revenue in Yogyakarta City, Indonesia}

ability of local governments to realize the received PBB revenue compared to the target of PBB revenue that has been set (Halim, 2001). So if it is associated with land and building taxes, then effectiveness is a measure used to measure the relationship between the results of land and building tax collections received and the tax revenue targets set.

To measure the level of effectiveness the following indicators can be used:

Table 2. Interpretation of Effectiveness Value

\begin{tabular}{|l|l|}
\hline Presentase & Kriteria \\
\hline$>100 \%$ & Sangat Efektif \\
\hline $90 \%-100 \%$ & Efektif \\
\hline $80 \%-90 \%$ & Cukup Efektif \\
\hline $60 \%-80 \%$ & Kurang Efektif \\
\hline$<60 \%$ & Tidak Efektif \\
\hline
\end{tabular}

Source: Ministry of Home Affairs, Ministry of Home Affairs No. 690,900,327 Year 1996

\section{METHODS}

The object of this research is the Regional Financial and Asset Management Agency in Yogyakarta (BPKAD) which is located on J. Kenari No.56, Muja Muju, Kec. Umbulharjo, Special Region of Yogyakarta 55165. The data obtained are land and building tax data and local revenue for a period of 5 years (2016 - 2020). The data used in this study mostly used quantitative descriptive data. The descriptive method is taken from the Yogyakarta regaarding land and building tax revenue data, and the Regional Original Revenue data for the 2016-2020 period. The type of data used in this study is secondary data obtained from reports in the BPKAD. Sampling in this study using a simple random technique.

In addition to secondary data, this research also obtained data through interviews. In an effort to obtain data and information related to this research as material or material for discussion purposes, data collection was taken to support this writing directly from the field in Regional Financial and Asset Management Agency, Yogyakarta City. The interview technique in this study is a structured interview, namely the interview is conducted by asking questions systematically and the questions asked have been prepared (Maleong, 2010: 186).

\section{RESULTS AND DISUCUSSIONS}

The data obtained is the Land and Building Tax Revenue for 2016-2020 as shown in table 1.

Table 3. Realization of Land and Building Tax Revenue of Yogyakarta in 2017-2020

\begin{tabular}{|l|l|l|l|l|}
\hline No & Year & Target (Rp) & Realization (Rp) & Increase/decrease \\
\hline 1 & 2016 & 53.000 .000 .000 & 55.250 .865 .938 & 2.250 .865 .038 \\
\hline 2 & 2017 & 66.000 .000 .000 & 75.942 .236 .947 & 9.942 .236 .947 \\
\hline 3 & 2018 & 75.000 .000 .000 & 76.403 .636 .198 & 1.403 .636 .198 \\
\hline 4 & 2019 & 82.500 .000 .000 & 86.550 .328 .189 & 4.050 .328 .189 \\
\hline 5 & 2020 & 82.500 .000 .000 & 96.517 .233 .954 & 14.017 .233 .954 \\
\hline
\end{tabular}

Source: Yogyakarta Financial and Asset Management Agency 2022

From the data above, it can be seen that during the last five years the achievement and development of Land and Building Tax realization has always been achieved and exceeded the set target and the amount of income received from the Land and Building Tax sector has always increased. As for the data above, which experienced the largest growth rate and with a realization value that was far greater than the set target budget, the one obtained in 2020 was Rp 96.517.233.954. Meanwhile, the budget target set is only Rp 82.500.000.000. So that in 2020, an increase of Rp 17.017.233.954 was obtained from the specified target value. The smallest realized value was shown in 2016, where the realized value obtained was only around Rp 55.250.865.938.

\section{Analysis of Land and Building Tax Effectiveness Ratio}

The effectiveness of the Yogyakarta's land and building tax revenue was analyzed using the effectiveness ratio with the following formula:

$$
\text { Effectiveness }=\frac{\text { Land Buiding Tax Revenue Realization }}{\text { Land Building Tax Revenue Target }} \times 100 \%
$$



Tax Sustainability: The Effectiveness and Contribution of Land and Building Taxes to Regional Original
Revenue in Yogyakarta City, Indonesia

Based on data of the land and building tax revenue target with data of the realization, the Effectiveness of Land and Building Tax receipts can be determined by the formula. So the level of effectiveness of land and building tax revenue in 2016 is $104.25 \%$, in 2017 is $115.06 \%$, in 2018 is $101.87 \%$, in 2019 is 104.91\%, and the level of effectiveness of land and building tax revenue in 2020 is $116.99 \%$.

Based on the effectiveness formula above, it can be seen the level of effectiveness of the 2016 - 2020 Land and Building Tax.

Table 4. Effectiveness of Land and Building Tax Revenue for Yogyakarta 2016-2020

\begin{tabular}{|l|l|l|l|l|}
\hline Year & Target (Rp) & Realization (Rp) & $\begin{array}{l}\text { Effectiveness } \\
\text { Level }\end{array}$ & Information \\
\hline 2016 & 53.000 .000 .000 & 55.250 .865 .938 & $104,25 \%$ & Very effective \\
\hline 2017 & 66.000 .000 .000 & 75.942 .236 .947 & $115,06 \%$ & Very effective \\
\hline 2018 & 75.000 .000 .000 & 76.403 .636 .198 & $101,87 \%$ & Very effective \\
\hline 2019 & 82.500 .000 .000 & 86.550 .328 .189 & $104,91 \%$ & Very effective \\
\hline 2020 & 82.500 .000 .000 & 96.517 .233 .954 & $116,99 \%$ & Very effective \\
\hline
\end{tabular}

From table 4. can be seen that the level of effectiveness of Land and Building Tax Revenur on Regional Original Revenue for the last five years has tended to rise and fall, but despite the increase and decrease in the value of its effectiveness, it shows a very effective percentage, because during these five years all tax targets are met. The percentage in 2016 reached $104.25 \%$, then in 2017 it increased with a percentage value of $115.06 \%$. Then in 2018 the percentage decreased by $101.87 \%$. In 2019 there was an increase with the percentage value of 104.91\%. and in 2020 there was a very large increase over 2016-2019 with a percentage value of $116.99 \%$. If it is drawn from the classification of effectiveness criteria, then the effectiveness value for the last five years shows a very effective value for the Regional Original Revenue of the Yogyakarta Government which has succeeded in achieving its goals by realizing land and building taxes so that it can be said that its objectives have been carried out in a very effective category.

\section{Analysis of Land and Building Tax Contribution to Regional Original Revenue}

The contribution of local taxes, especially Land and Building Tax to Regional Original Revenue, is a ratio used to find out how much Land and Building Tax contributes to Regional Original Revenue in Yogyakarta.

The data obtained is the Regional Original Revenue for 2016-2020 as shown in table 5.

Table 5. Realization of Regional Original Revenue of Yogyakarta in 2017-2020

\begin{tabular}{|l|l|l|}
\hline No & Year & Realization (Rp) \\
\hline 1 & 2016 & 55.250 .865 .938 \\
\hline 2 & 2017 & 75.942 .236 .947 \\
\hline 3 & 2018 & 76.403 .636 .198 \\
\hline 4 & 2019 & 86.550 .328 .189 \\
\hline 5 & 2020 & 96.517 .233 .954 \\
\hline
\end{tabular}

Source: Yogyakarta Financial and Asset Management Agency 2022

To calculate the amount of Land and Building Tax Contribution the following formula is used:

$$
\text { Contribution }=\frac{\text { Realization of Land and Building Tax }}{\text { Realization of Regional Original Revenue }} \times 100 \%
$$

Based on the data, the revenue from the Land and Building Tax Contribution to the Yogyakarta's Original Revenue can be determined by the formula. The contribution rate in 2016 was $10.22 \%$, in 2017 was $11.56 \%$, in 2018 was $10.45 \%$, in 2019 was $12.60 \%$, and the Land and Building Tax Contribution to the Yogyakarta's Original Revenue in 2020 was $17.14 \%$. 
Tax Sustainability: The Effectiveness and Contribution of Land and Building Taxes to Regional Original
Revenue in Yogyakarta City, Indonesia

Table 6. Contribution of Land and Building Tax Revenue to the Yogyakarta's Original Revenue 2016-2020

\begin{tabular}{|l|l|l|l|l|}
\hline Year & $\begin{array}{l}\text { Realization of } \\
\text { Land Building } \\
\text { Tax Revenue }\end{array}$ & $\begin{array}{l}\text { Realization of } \\
\text { Regional Original } \\
\text { Revenue }\end{array}$ & $\begin{array}{l}\text { Contributin } \\
\text { Rate }\end{array}$ & Information \\
\hline 2016 & 55.250 .865 .938 & 540.504 .305 .181 & $10,22 \%$ & Less \\
\hline 2017 & 75.942 .236 .947 & 657.049 .376 .703 & $11,56 \%$ & Less \\
\hline 2018 & 76.403 .636 .198 & 667.493 .075 .470 & $11,45 \%$ & Less \\
\hline 2019 & 86.550 .328 .189 & 689.049 .725 .509 & $12,60 \%$ & Less \\
\hline 2020 & 96.517 .233 .954 & 563.174 .371 .396 & $17,14 \%$ & Less \\
\hline
\end{tabular}

From the table 6, it can be seen from the contribution given by the Land and Building Tax to Regional Original Revenue (PAD) for the last five years which shows a figure that is less than $17 \%$. Where the value of the contribution shows the presentation of Less. The presentation in 2016 the realization of Land and Building Tax (PBB) contributed 10.22\%, this shows that the contribution of PBB given to the realization of PAD is categorized as Less. In the following year, 2017, the realization of PBB contributed $11.56 \%$. It can be seen that the contribution in 2017 increased from the previous year. It can also be said that the contribution of PBB given to the realization of PAD is also categorized as less. Furthermore, in 2018 the realization of PBB contributed $11.46 \%$. It can also be seen that the contribution in 2018 decreased from the previous year. This is also the same as in 2017 where the contribution of PBB given to the realization of PAD is categorized as less. In 2019, the realization of PBB contributed $12.60 \%$. It can be seen that the contribution in 2019 increased compared to the previous year. However, the contribution made to PAD is still lacking. In 2020 the realization of the PBB contributed 17.14\%, it can also be seen that the contribution in 2020 also increased from the previous year. Although the increase that occurred from 2016-2020 increased, the contribution given to PAD was categorized as less. If it is drawn on the clarification of the contribution criteria, the contribution value for 2016-2020 shows the category of not contributing to the Yogyakarta's Original Regional Revenue.

\section{DISCUSSION}

Based on the analysis of the effectiveness and contribution of the Land and Building Tax to the Yogyakarta's Original Revenue, the level of effectiveness of the 2016-2020 land and building tax is said to be very effective because it reaches the targeted level with a presentation of $>100 \%$. The legal basis for implementing the Land and Building Tax (PBB) is Law Number 28 of 2009 concerning Regional Taxes and Regional Retribution where the rules are further detailed through the Regional Regulation of the Yogyakarta City Number 2 of 2011 concerning Land and Building Taxes. The increasing amount of the Land and Building Tax (PBB) Revenue for Yogyakarta every year gives a signal that compliance with tax obligations of the community is high enough to contribute to development in the region. Not only that, development can also be maintained because local tax revenues are quite good.

It is different with the contribution of Land and Building Tax to Yogyakarta's Original Revenue, although it is still considered insufficient, because the value obtained from the calculation results in a value between $10.10 \%-20 \%$ or with a less percentage, but the percentage has increased in the last 5 years. It can be projected in the next few years, that if the Land and Building Tax (PBB) Revenue is consistent and exceeds the target every year, the percentage and criteria for contributions will increase. This is in accordance with the proposed analysis, the Land and Building Tax has a contribution to the Yogyakarta's Original Revenue. Although the contribution of the Land and Building Tax is not that large, the Land and Building Tax contributes to the Yogyakarta's Original Regional Revenue.

\section{CONCLUSIONS}

Based on the results, it can be seen that the level of effectiveness of the Land and Building Tax has experienced a very effective growth, recorded in 2016-2020, the level of effectiveness of the Yogyakarta's Land and Building Tax has always been in the very effective category, where the realization is more basic than the targeted. Meanwhile, for the achievement of the contribution of Land and Building Tax to the Yogyakarta's Original Revenue, it is in the category of less contributing, although the realization in the last 5 years has always been above the target and the income has increased significantly.

Based on the conclusions, the researcher recommends that the Yogyakarta Government should increase the target of Land and Building Tax revenue so that it will spur local tax officials to improve their performance, and it is hoped that Land and Building Tax revenue will also increase along with the increase in the target set. If the revenue increases, then of course it will increase the contribution of Land and Building Tax receipts to Regional Original Revenue. For further researchers, in addition to 


\section{Tax Sustainability: The Effectiveness and Contribution of Land and Building Taxes to Regional Original Revenue in Yogyakarta City, Indonesia}

effectiveness and contribution, other ratios can also be calculated, for example the level of efficiency in the implementation of Land and Building Tax.

\section{REFERENCES}

1) Fitriani, A. P., Handayan, S. R., and Z. A, Z. (2015). "The Effectiveness of Hotel Taxes as a Source of Regional Tax Revenue (Study at the Regional Revenue Service of Kediri City)". Journal of Business Administration S1 Universitas Brawijaya, 21(2), 1-6.

2) Habib, M.M. 2015. "Analysis of the Implementation of Decentralization in City/Regency Regional Autonomy". Journal of Pancasila and Citizenship Education, 3 (2), 117-124.

3) Halim, A., 2012. "Regional Financial Management". Yogyakarta: UPP STIM YKPN.

4) Huda M.N. and Wicaksono, G. 2021. "Analysis of the Effectiveness and Contribution of Rural and Urban Land and Building Tax Revenues to Yogyakarta City Original Revenue". Journal of Educoretax, 1(4), $284-290$.

5) Kadir, S. (2017). "Effectiveness of Hotel and Restaurant Tax Collection and Development Strategies in Kotabaru Regency". ISSN Journal of Business and Development, 6(1), 2541-178X.

6) Law, No. 23 of 2014 concerning Regional Government.

7) Law, No. 33 of 2004 concerning the Financial Balance between the Central Government and Regional Governments.

8) Law, No. 34 of 2000 concerning Regional Taxes and Retribution.

9) McCluskey, William J,. \& France Plimmer. 2011. "The Creation of Fiscal Space for the Property Tax: The Case of Central And Eastern Europe". International Journal of Strategic Property Management, 15(2),123-138.

10) Norregaard, John and Norregaard, John. 2013. "Taxing Immovable Property Revenue Potential and Implementation Challenges". IMF Working Papers. No. 13/129, Available at SSRN: https://ssrn.com/abstract=2280635 or http://dx.doi.org/10.2139/ssrn.2280635.

11) Nuradhawati, R. 2019. "The Dynamics of Centralization and Decentralization in Indonesia". Journal of the Praja Academy, 2 (01), 152-170.

12) Purnamasari, R.Y. 2017. "Analysis of the Contribution of Regional Taxes to Regional Original Income in the Department of Financial and Asset Management of Rokan Hulu Regency". UPP Management Study Program Student Journal, 2 (2), 109911, 1-9.

13) Rawung, Natalia. 2016. "Analysis of Regional Original Income and its Recording at the Manado City Revenue Service. EMBA Journal, 4(1), 496-502.

14) Sari, N.T. 2012. "Analysis of Hotel Tax Contribution to Regional Original Income in the City of Semarang (Case Study at the Office of Financial Management)". Faculty of Economics and Business, Dian Nuswantoro University, Semarang.

15) Sugiyono, P.D. 2009. "Qualitative Research Methods, Qualitative and R \& D". Alfabeta, Bandung.

16) Research and Development Team Depdagri Fisipol UGM 1991 regarding Contribution Criteria.

17) Utomo, S.W., J. M. 2020. "Effectiveness and Contribution of Land and Building Tax Revenues to Increase in Madium City's Original Revenue". FIFA: Scientific Forum on Accounting Education, 8(1).

18) Walakandou, R. 2013. "Analysis of Hotel Tax Contribution to Regional Original Income (PAD) in Manado City". Journal of Research in Economics, Management, Business and Accounting, 1(3), 722-729.

19) Waluyo., 2013, Understanding Taxes. PT. Rajawali Grafindo Pustaka, Jakarta.

20) Waluyo,. 2001, Tax Law. PT. Rajawali Grafindo Pustaka, Jakarta.

21) Wicaksono, G., \& Pamungkas, T.S. 2017. "Analysis of the Effectiveness and Contribution of Land and Building Tax Revenue to Jember Regency's Original Revenue". Journal of Stie Semasang (Electronic Edition), 9 (1), 67-76.

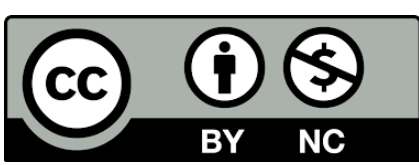

There is an Open Access article, distributed under the term of the Creative Commons Attribution - Non Commercial 4.0 International (CC BY-NC 4.0)

(https://creativecommons.org/licenses/by-nc/4.0/), which permits remixing, adapting and building upon the work for non-commercial use, provided the original work is properly cited. 